\title{
Preliminary Study on Taxonomic Review Using Histological Sections of Some Iberian Species from the Genus Quercus L. (Fagaceae)
}

\author{
Sara del Río1, Rafael Álvarez ${ }^{2}$, Adoración Candelas², Silvia González-Sierra33, \\ Luis Herrero' ${ }^{1}$, Angel Penas ${ }^{1}$ \\ ${ }^{1}$ Department of Biodiversity and Environmental Management (Botany), Faculty of Biology and Environmental \\ Sciences, Mountain Livestock Institute (CSIC-University of León), University of León, León, Spain \\ ${ }^{2}$ Departamento de Biología Molecular-Área de Biología Celular, Facultad de Ciencias Biológicas y Ambientales, \\ Universidad de León, León, Spain \\ ${ }^{3}$ Laboratorio de Microscopía, Centro Nacional de Investigación sobre la Evolución Humana (CENIEH), Burgos, \\ Spain \\ Email: ralvn@unileon.es
}

Received 30 May 2014; revised 12 July 2014; accepted 13 August 2014

Copyright (C) 2014 by authors and Scientific Research Publishing Inc.

This work is licensed under the Creative Commons Attribution International License (CC BY).

http://creativecommons.org/licenses/by/4.0/

(c) (i) Open Access

\section{Abstract}

The taxonomy of the genus Quercus is the subject of ongoing scientific interest at the present time. Classically the scanning electron microscope is and has been used for the study of leaf surfaces, particularly to characterise the trichomes, stomata and epicuticular waxes. In the present work, in addition to using the SEM, histological sections from a group of taxa from the northern Iberian Peninsula are studied under the optical microscope. Specifically, the study concerns the leaves of $Q$ Qercus robur subsp. robur, $Q$. orocantabrica, $Q$. petraea and $Q$. pyrenaica, and of possible hybrids between $Q$. orocantabrica and $Q$. petraea and between $Q$. orocantabrica and $Q$. pyrenaica. The results highlight histological differences between $Q$. robur and $Q$. orocantabrica, and also differentiate the morphological characteristics of $Q$. petraea and $Q$. pyrenaica. Similarities can also be observed between $Q$. petraea and its possible hybrid with $Q$. orocantabrica, and between $Q$. pyrenaica and its hybrid with $Q$. orocantabrica. The aspects observed under the optical microscope complement the observations obtained by means of the scanning electron microscope, and as a consequence of this, two new nothospecies are described: $Q$. xpuentei $(Q$. orocantabrica $\times Q$. petraea) and Q. xpenasii ( $Q$. orocantabrica $\times Q$. pyrenaica).

\footnotetext{
${ }^{*}$ Corresponding author.
} 
Keywords

Histology, Iberian Peninsula, Optical Microscopy, Quercus, SEM

\section{Introduction}

In addition to the inherent difficulties involved in the taxonomy of the genus Quercus [1]-[4], there is also the fact of the frequent occurrence of interspecies hybridisations [4] [5].

The different species of Quercus (and its hybrids) have been distinguished based on the morphology of the acorns [6] [7] and on genetic and biochemical markers [8]-[10]. However the most frequently used method has been and continues to be the study of the leaf morphology [10]-[12].

The morphological characteristics of leaves are evidently subject to genetics. But in addition to these characteristics, there is also an influence of ecological factors, phenological cycles, growth rhythms, etc. [13] [14], which call for the utmost care when collecting samples for taxonomic studies. As far as it is practical, it is necessary to unify the greatest possible number of variables. For example in the specific case of Quercus, samples must be taken at the same time of year [15]. Furthermore factors deserving special attention include the physical placement of the leaves on the tree as a whole: leaves located on the periphery, as opposed to leaves located on the interior. It is also necessary to consider the geographic location of the tree itself, taking care to avoid sampling plants in border areas of the forest stands. In both cases the aim is to avoid any possible morphological differences which might exist between so-called sun and shade leaves [16].

In the genus Quercus the macro-morphological characters are taxonomically inadequate, particularly when studying hybrids [17]. For years most researchers have used the SEM to recognise the characteristics of the leaf surface [15] [18] [19]. The specific target of the investigation is usually the trichomes, the stomata and the epicuticular waxes [20].

Trichomes have long been used to recognise the species in numerous groups of angiosperms, either due to their presence/absence or due to the presence of different types [21]. In the leaves of the genus Quercus, two types of trichomes can be observed: some glandular, and some non-glandular. Glandular trichomes do not present a great variation, and thus their taxonomical usefulness is fairly limited [22] [23]. However non-glandular trichomes do manifest considerable variations, and have been used as taxonomical tools since 1936 [24]. The classification and terminology of trichomes used in SEM studies is as indicated by authors such as Hardin [25]-[27] and Jones [28].

Furthermore, the morphology of the stomata has also classically been used to differentiate species. With the use of the SEM, these studies have been supplemented with the study of the epicuticular waxes per se; the most recent overview of the group corresponds to Barthlott et al. [29], and has been used on many occasions in taxonomy (for example [30]-[32]). In the specific case of Quercus L., studies focused on the variability of the stomata, with particular emphasis on the pore delimited by the guard cells, and the deposit of epicuticular waxes around the rim of pore [4] [20] [33] [34].

There are very few taxonomical studies in the bibliography involving histological sections of leaves from different species of Quercus. Recently Nicolic et al. [14] have described significant differences between different genotypes of leaves of $Q$. robur based on the thickness of the cuticle, height of the adaxial epidermis, etc.

The present work contains a study of the characteristics of the trichomes, stomata and epicuticular waxes from six Quercus taxa carried out with SEM. This study is combined with another purely histological investigation with optical microscopy. It is presented as a preliminary work, on the understanding that further in-depth investigation of the aspects revealed here will confer greater weight on the results.

\section{Materials and Methods}

A summary of the methods used is shown in Table 1.

Five leaves of Q. robur, Q. orocantabrica, Q. petraea, Q. pyrenaica, Q. xpuentei and Q. xpenasii collected in the north of the Iberian Peninsula in August were fixed in situ in FAA (formalin—acetic acid—alcohol); these materials are on deposit in the LEB “Jaime Andrés Rodríguez" with the following reference numbers: 
Table 1. Techniques followed in this work. Fixatives, hardening methods (Inclusion), microtomes (Sections), treatment of the sections, staining, mounting media, and microscopes used for routine method and other treatments (Target).

\begin{tabular}{|c|c|c|c|c|c|c|c|}
\hline Target & Fixation & Inclusion & Sections & Treatment & Staining & Mounting & Microscope \\
\hline Routine method & FAA & Paraplast & Parafine microtome & Usual technique & Safranin-Fast green & Entellan & Bright-field/Polarized-light \\
\hline Clearing & FAA & Paraplast & Parafine microtome & $\mathrm{NaClO}$ & Safranin-Fast green & Entellan & Bright-field/Polarized-light \\
\hline Starch & FAA & Paraplast & Parafine microtome & Usual technique & Lugol & Entellan & Bright-field/Polarized-light \\
\hline Epidermis & FAA & - & - & Jeffrey's method & Basic Fuchsin & Entellan & Bright-field \\
\hline Autofluorescence & FAA & Paraplast & Parafine microtome & Usual technique & - & Entellan & Fluorescence \\
\hline Epidermis & FAA & - & - & Gold coated & - & - & SEM \\
\hline
\end{tabular}

\subsection{Quercus robur L. subsp. robur}

Asturias: Concejo de Amieva (Sames, La Valdorada) (LEB 107760) (10-8-2010) (30TUN2828992054) at $194 \mathrm{~m}$ in a south-west orientation. Leg.: A. Penas, S. del Río, L. González de Paz \& I. Fuertes.

Asturias: Concejo de Amieva (Sames, La Valdorada) (LEB 107761) (10-8-2010) (30TUN2829092045) at 193 $\mathrm{m}$ in a south-west orientation. Leg.: A. Penas, S. del Río, L. González de Paz \& I. Fuertes.

Asturias: Concejo de Amieva (Sames, La Valdorada) (LEB 107762) (10-8-2010) (30TUN2822892000) at 204 $\mathrm{m}$ in a south-west orientation. Leg.: A. Penas, S. del Río, L. González de Paz \& I. Fuertes.

Asturias: Concejo de Amieva (Sames, La Valdorada) (LEB 107763) (10-8-2010) (30TUN2825492025) at 192 $\mathrm{m}$ in a south-west orientation. Leg.: A. Penas, S. del Río, L. González de Paz \& I. Fuertes.

Asturias: Concejo de Amieva (Sames, La Valdorada) (LEB 107764) (10-8-2010) (30TUN2823692028) at 201 $\mathrm{m}$ in a south-west orientation. Leg.: A. Penas, S. del Río, L. González de Paz \& I. Fuertes.

\subsection{Quercus orocantabrica Rivas Mart., Penas, T.E. Díaz and Llamas}

León: Puerto de las Señales (LEB 107779) (9-8-2010) (30TUN1633071817) in a southern orientation at $1541 \mathrm{~m}$ in microforest. Leg.: A. Penas, S. del Río, L. González de Paz \& I. Fuertes.

León: Puerto de las Señales (LEB 107780) (9-8-2010) (30TUN1632871822) in a southern orientation at 1542 $\mathrm{m}$ in microforest. Leg.: A. Penas, S. del Río, L. González de Paz \& I. Fuertes.

León: Puerto de las Señales (LEB 107781) (9-8-2010) (30TUN1633571823) in a southern orientation at 1543 $\mathrm{m}$ in microforest. Leg.: A. Penas, S. del Río, L. González de Paz \& I. Fuertes.

León: Puerto de las Señales (LEB 107782) (9-8-2010) (30TUN1634571826) in a southern orientation at 1545 $\mathrm{m}$ in microforest. Leg.: A. Penas, S. del Río, L. González de Paz \& I. Fuertes.

León: Puerto de las Señales (LEB 107783) (9-8-2010) (30TUN1634171829) in a southern orientation at 1547 m in microforest. Leg.: A. Penas, S. del Río, L. González de Paz \& I. Fuertes.

\subsection{Quercus petraea (Matt.) Liebl.}

León: Los Casares-Berrunde (Oseja de Sajambre) (LEB 107765) (10-8-2010) (30TUN3589976959) at 885 m in a south-west orientation. Leg.: A. Penas, S. del Río, L. González de Paz \& I. Fuertes.

León: Los Casares-Berrunde (Oseja de Sajambre) (LEB 107766) (10-8-2010) (30TUN3590977097) at $909 \mathrm{~m}$ in a south-west orientation. Leg.: A. Penas, S. del Río, L. González de Paz \& I. Fuertes.

León: Los Casares-Berrunde (Oseja de Sajambre) (LEB 107767) (10-8-2010) (30TUN3585576986) at $892 \mathrm{~m}$ in a south-west orientation. Leg.: A. Penas, S. del Río, L. González de Paz \& I. Fuertes.

León: Los Casares-Berrunde (Oseja de Sajambre) (LEB 107768) (10-8-2010) (30TUN3591576950) a 876 m in a south-west orientation. Leg.: A. Penas, S. del Río, L. González de Paz \& I. Fuertes.

León: Los Casares-Berrunde (Oseja de Sajambre) (LEB 107769) (10-8-2010) (30TUN3591776946) at $872 \mathrm{~m}$ in a south-west orientation. Leg.: A. Penas, S. del Río, L. González de Paz \& I. Fuertes.

\subsection{Quercus pyrenaica Willd.}

León: Between Cistierna and Villapadierna (LEB 107787) (10-8-2010) (30TUN2477533998) at $880 \mathrm{~m}$ in oak forest. Leg.: A. Penas, S. del Río, L. González de Paz and I. Fuertes. 
León: Between Cistierna and Villapadierna (LEB 107774) (10-8-2010) (30TUN2479333969) at $880 \mathrm{~m}$ in oak forest. Leg.: A. Penas, S. del Río, L. González de Paz \& I. Fuertes.

León: Between Cistierna and Villapadierna (LEB 107772) (10-8-2010) (30TUN2473434028) at $885 \mathrm{~m}$ in oak forest. Leg.: A. Penas, S. del Río, L. González de Paz \& I. Fuertes.

León: Between Cistierna and Villapadierna (LEB 107773) (10-8-2010) (30TUN2474634015) at $879 \mathrm{~m}$ in oak forest. Leg.: A. Penas, S. del Río, L. González de Paz \& I. Fuertes.

León: Between Cistierna and Villapadierna (LEB 107759) (10-8-2010) (30TUN2479333968) at $882 \mathrm{~m}$ in oak forest. Leg.: A. Penas, S. del Río, L. González de Paz \& I. Fuertes.

\subsection{Quercus xpuentei S. Rivas Mart., T.E. Díaz, Penas, del Río, L. Herrero and R. Álvarez}

León: Puerto de las Señales (LEB 107784) (9-8-2010) (30TUN1515570427) in an east-south-east orientation at $1373 \mathrm{~m}$ in beech forest. Leg.: A. Penas, S. del Río, L. González de Paz \& I. Fuertes.

León: Puerto de las Señales (LEB 107785) (9-8-2010) (30TUN1522570454) in an east-south-east orientation at $1377 \mathrm{~m}$ in beech forest. Leg.: A. Penas, S. del Río, L. González de Paz \& I. Fuertes.

León: Puerto de las Señales (LEB 107786) (9-8-2010) (30TUN1529970515) in an east-south-east orientation at $1386 \mathrm{~m}$ in beech forest. Leg.: A. Penas, S. del Río, L. González de Paz \& I. Fuertes. (ISOTYPUS)

León: Puerto de las Señales (LEB 107292) (9-8-2010) (30TUN1527270478) in an east-south-east orientation at $1385 \mathrm{~m}$ in beech forest. Leg.: A. Penas, S. del Río, L. González de Paz \& I. Fuertes.

León: Puerto de las Señales (LEB 107293) (9-8-2010) (30TUN1516770417) in an east-south-east orientation at 1385 m in beech forest. Leg.: A. Penas, S. del Río, L. González de Paz \& I. Fuertes.

\subsection{Quercus xpenasii S. Rivas Mart., T.E. Díaz, del Río, L. Herrero and R. Álvarez}

León: Valle del arroyo de Faeda (Cabrera Baja) (LEB 107770) (16-8-2010) (30TPG93176/792UN) at 1672 m in a western orientation. Leg.: L. González de Paz, S. del Río \& A. Penas.

León: Valle del arroyo de Faeda (Cabrera Baja) (LEB 107771) (16-8-2010) (30TPG9362979862) at $1757 \mathrm{~m}$ in a west-south-western orientation. Leg.: L. González de Paz, S. del Río \& A. Penas.

León: Valle del arroyo de Faeda (Cabrera Baja) (LEB 107287) (16-8-2010) (30TPG9362979862) at $1756 \mathrm{~m}$ in a west-south-western orientation. Leg.: L. González de Paz, S. del Río \& A. Penas.

León: Valle del arroyo de Faeda (Cabrera Baja) (LEB 107288) (16-8-2010) (30TPG9320079207) at $1410 \mathrm{~m}$ in a western orientation. Leg.: L. González de Paz, S. del Río \& A. Penas. (ISOTYPUS).

In all cases, leaves were taken from around the periphery of the trees and facing in a similar direction with regard to the sun, and never from trees which were on the border of the group of trees of the same species. In the laboratory they were processed for observation using optical and electronic microscopy. For optical microscopy, samples were taken from the middle part of the leaf, including the midvein. These samples (measuring about 2 $\mathrm{cm}$ long) were dehydrated in an ethanol series and embedded in paraplast using isoamylacetate as an intermediate liquid. From each paraffin block obtained, serial cuts with a thickness of $12 \mu \mathrm{m}$ were made in a rotatory microtome. The sections were arranged on six microscope slides previously impregnated with Mayer albumin. The paraplast was removed from the odd-numbered slides (1st, 3rd and 5th) and they were dyed with Safranin-Fast green. The even-numbered slides were: a) dyed with Lugol for starch detection; b) treated with sodium hypochlorite to eliminate cell content, and subsequently dyed with Safranin-Fast green; c) not dyed, and observed with an epifluorescence microscope. All the slides were permanently mounted using Entellán as a mounting medium. The observations were made in a bright-field microscope, polarized light microscope and epifluorescence microscope. By means of an ocular grid in a bright-field microscope, the thicknesses of the cut lamina were measured: 7 points were randomly chosen from each of the samples studied in which no veins were located. Likewise, $1 \mathrm{~cm}^{2}$ samples of leaf lamina were digested by Jeffrey's method to obtain the leaf epidermises. The samples were maintained about 72 hours in the Jeffrey's liquid (chromic acid and nitric acid). The epidermises obtained, from the adaxial and abaxial surfaces of each sample, were dyed with Basic Fuchsine, permanently mounted with Entellán and studied in a bright-field optical microscope.

For the observation with the scanning electron microscope (SEM) samples of leaf lamina were taken measuring about $0.5 \mathrm{~cm}^{2}$. The samples were dehydrated in an ethanol series and coated with gold for observation in a FEI Quanta 600 environmental scanning electron microscope (ESEM).

With the data obtained for the thickness of the leaf lamina, a one-way ANOVA was conducted (statistical 
package R v. 2.15.0). After the ANOVA, and with a significant result, a post-hoc analysis was performed by means of multiple comparison using Tukey's method (Tukey’s Honest Significant Difference).

\section{Results}

Table 2 shows a summary of the results.

All the Quercus leaves studied share a hypostomatic arrangement of the stomata; that is to say, stomata can only be seen on the abaxial leaf surface.

On the lamina they present (from the adaxial to the abaxial) (Figure 1(a)): non-ornamented cuticle with epicuticular waxes of the membranous platelet type (Figure 2(a)); uniseriate epidermis with large cuboidal/squamous cells; palisade parenchyma; spongy parenchyma (these are thus dorsiventral leaves); uniseriate epidermis with small cuboidal cells; anomocytic stomata slightly raised above the surface of the epidermis (Figures 1(d)-(f), Figures 2(b)-(c) and always elongated (Figures 2(i)-(j)); trichomes: some-glandular-present in all the samples studied (Figures 2(b)-(e)), and others—non-glandular-present only in some of the samples studied

Table 2. Summary of the observations carried out of the microscopic structure of the lamina and midvein of $Q$. robur, $Q$. orocantabrica, Q. petraea, Q. pyrenaica, Q. xpuentei and Q. xpenasii. In the thickness of the lamina, the symbol in superscript indicates the absence of significant differences. The presence $(+)$ and absence $(-)$ is indicated. In some cases the observer's subjective estimate is given, from a low presence $(+)$ to a high presence $\left({ }^{+++}\right)$. ab, abaxial; ad, adaxial; Cub, cuboidal; Squa, squamous.

\begin{tabular}{|c|c|c|c|c|c|c|}
\hline & Q. robur & Q. orocantabrica & Q. petraea & Q. pyrenaica & Q. oro-pet & Q. oro-pyr \\
\hline \multicolumn{7}{|l|}{ LAMINA } \\
\hline Thickness (mm) & $0.124^{\mathrm{c}}$ & $0.182^{\mathrm{b}}$ & $0.165^{\mathrm{b}}$ & $0.177^{\mathrm{b}}$ & $0.218^{\mathrm{a}}$ & $0.218^{\mathrm{a}}$ \\
\hline Epidermis_-adaxial & Uniseriate & Uniseriate & Uniseriate & Uniseriate & Uniseriate & Uniseriate \\
\hline Cell shape & Squamous & Squamous & Cub/Squa & Cub/Squa & Cub/Squa & Cub/Squa \\
\hline Cell height & Low & Low & High & High & High & High \\
\hline Stomata & - & - & - & - & - & - \\
\hline Palisade parenchyma & + & + & + & + & + & + \\
\hline Number of cells & 1 & $1+1$ & $1+1$ & 2 & $1+1$ & 2 \\
\hline Spongy parenchyma & + & + & + & + & + & + \\
\hline Epidermis_-abaxial & Uniseriate & Uniseriate & Uniseriate & Uniseriate & Uniseriate & Uniseriate \\
\hline Cell shape & Cub/Squa & Cuboidal & Cuboidal & Cuboidal & Cuboidal & Cuboidal \\
\hline Stomata & + & + & + & ++ & + & ++ \\
\hline Shape & Elongated & Elongated & Elongated & Elongated & Elongated & Elongated \\
\hline Epicuticular waxes & +++ & +++ & + & ++ & + & ++ \\
\hline Glandular trichomes & $+a b$ & $+a b$ & $+a b$ & +ad and ab & $+a b$ & +ad and ab \\
\hline Non-glandular trichomes & - & - & $+a b$ & +ad and ab & $+a b$ & +ad and ab \\
\hline Number of branches & - & - & 4 & 4 or more & 4 & 4 or more \\
\hline Crystals & $-1+$ & +++ & ++ & + & +++ & +++ \\
\hline Starch & ++ & +++ & +++ & ++ & + & ++ \\
\hline \multicolumn{7}{|l|}{ MIDVEIN } \\
\hline Epidermis_-adaxial & Uniseriate & Uniseriate & Uniseriate & Uniseriate & Uniseriate & Uniseriate \\
\hline Annular collenchyma & + & + & + & + & + & + \\
\hline Storage parenchyma & + & + & + & + & + & + \\
\hline Bundle-sheath & + & + & + & + & + & + \\
\hline Vascular bundle & + & + & + & + & + & + \\
\hline Epidermis_-abaxial & Uniseriate & Uniseriate & Uniseriate & Uniseriate & Uniseriate & Uniseriate \\
\hline Crystals & + & ++ & $-1+$ & - & ++ & +++ \\
\hline
\end{tabular}



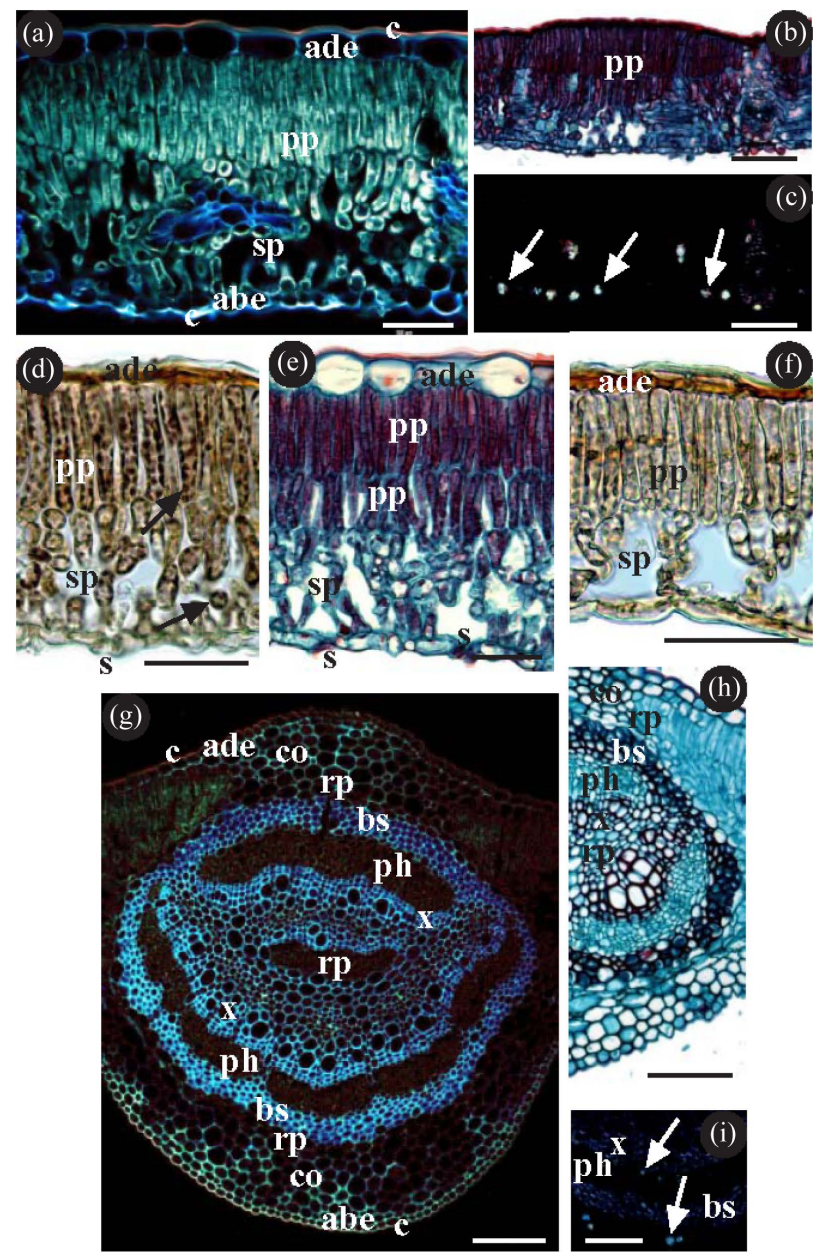

Figure 1. (a)-(i) Lamina and midvein of Quercus; (a)-(f) Transverse section of the lamina; (a) Tissue composition of the lamina, showing the cuticles (c) (the adaxial cuticle thicker than the abaxial), the epidermis (the adaxial (ade) with larger cells than the abaxial (abe)), the palisade parenchyma (pp) and the spongy parenchyma (sp). (b)-(c) The same image as in (b), observed with a bright-field microscope, is shown in (c), observed with a polarized light microscope. The arrows indicate calcium oxalate crystals; (d) Histochemical detection of starch. The arrows indicate the presence of starch both on the palisade parenchyma and on the spongy parenchyma. (e)-(f) Palisade parenchyma with two cell layers (e) or with a single cell layer (f). (g)-(i) Transverse section of the midvein. (g)-(h) Tissue composition of the midvein, showing the cuticles and epidermis, annular collenchyma (co), storage parenchyma (rp) and the transport tissues (xylem (x) y phloem (ph)) surrounded by a bundle-sheath (bs) of sclerenchyma fibres; (i) The arrows indicate the presence of calcium oxalate crystals both inside and outside the bundle-sheath. (a) Q. xpuentei; (b)-(d) (g) Q. orocantabrica; (e) (i) Q. xpenasii; (f) (h) Q. robur; (a) (b) Epifluorescence microscope; (b) (d)-(f) (h) Bright-field optical microscope. (c) (i) polarized light microscope; (b) (e) (h) Safranin-Fast green; (d) (f) Lugol.; (h) Clearing with sodium hypochlorite. Abbreviations: abe abaxial epidermis; ade adaxial epidermis; bs bundle-sheath; c cuticle; co collenchyma; ph phloem; pp palisade parenchyma; rp storage parenchyma; s stomata; sp spongy parenchyma; $\mathrm{x}$ xylem. Bar (a)-(c) (g)-(i) = $100 \mu \mathrm{m}$; (d)-(f) $=50 \mu \mathrm{m}$.

(Figure 2(b), Figures 2(f)-(h)); non-ornamented cuticle, generally not as thick as on the adaxial; and like in the adaxial, with epicuticular waxes of the membranous platelet type; the stomata may have epicuticular waxes which do not extend as far as the pore region (Figures 2(i)-(j)); furthermore calcium oxalate crystals can be observed, particularly as druses, located preferentially on the spongy parenchyma (Figures 1(b)-(c)); the starch detected is located on the chloroplasts of both parenchyma (Figure 1(d)).

In the midvein, all the samples studied present (from the adaxial to the abaxial surface) (Figures $\mathbf{1}(\mathrm{g})$-(h)): cuticle; uniseriate epidermis with small cells; annular collenchyma; storage parenchyma; transport tissues (xylem 

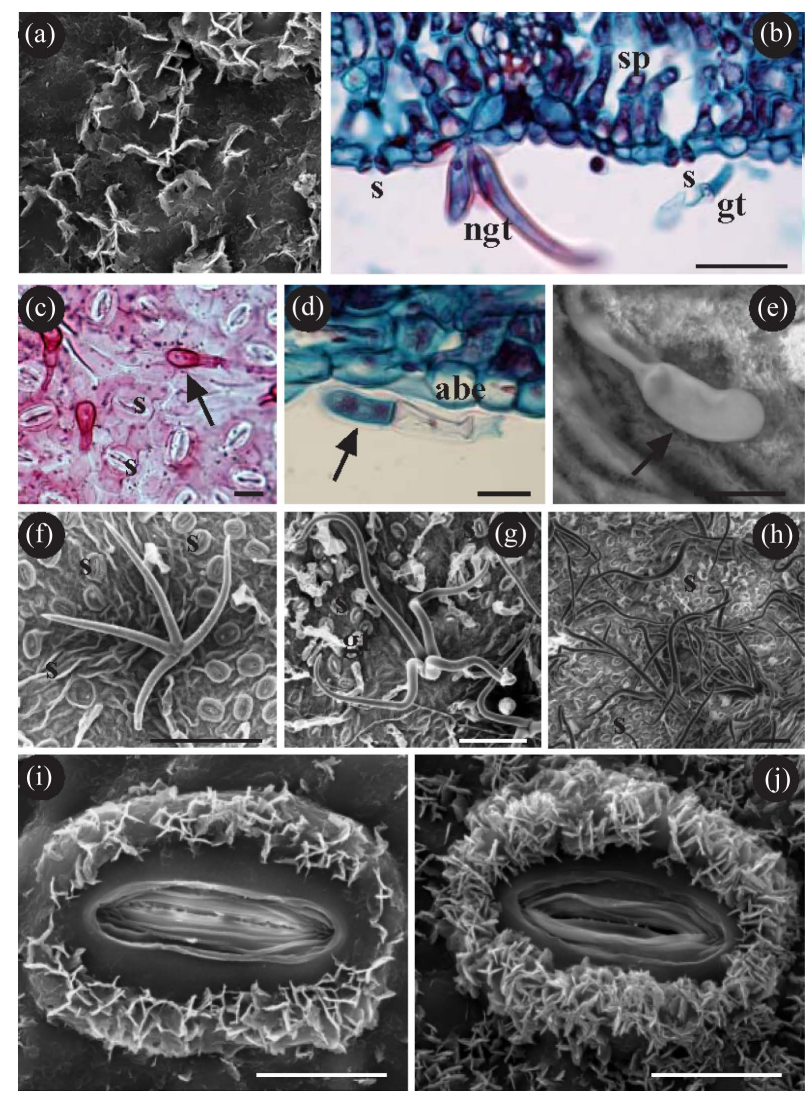

Figure 2. (a)-(i) Epidermis of Quercus; (a) Epicuticular waxes of the membranous platelet type; (b) Transverse section of the lamina showing the presence of stomata (s) (slightly raised), and glandular (gt) and non-glandular trichome (ngt); (c)-(e) Glandular trichomes. In the three illustrations, the arrows indicate the distal cell of the glandular trichomes; (f)-(h) Non-glandular trichomes. In (f) a non-glandular trichome with four branches (not distant from the surface). In (g)-(h) trichomes with four or more branches (long and distant from the surface); (i) (j) Stomata with epicuticular waxes which are in no case deposited around the rim of pore. In (i) with low density of epicuticular waxes and in (j) with high density. (a) (d) (e) Q. xpuentei; (b) (g) (h) Q. xpenasii; (c) (j) Q. robur; (f) (i) Q. petraea; (a) (e)-(j) SEM; (b)-(d) Bright-field optical microscope; (b) (d) Safranin-Fast green; (c) Jeffrey’s method, Basic Fuchsine. Abbreviations: abe abaxial epidermis; gt glandular trichome; ngt non-glandular trichome; s stomata; sp spongy parenchyma. $\operatorname{Bar}(\mathrm{a})$ (i) (j) $=10 \mu \mathrm{m}$; (b) $=50 \mu \mathrm{m}$; (c)-(e) $=20 \mu \mathrm{m}$; (f)-(h) = 100 $\mu \mathrm{m}$.

and phloem) surrounded by a bundle-sheath (of sclerenchyma fibres); storage parenchyma; annular collenchyma; uniseriate epidermis; cuticle; calcium oxalate crystals_-both druses and prisms—can also be seen, both inside and outside the bundle-sheath (Figure 1(i)); the starch is scarce and located in the storage parenchyma. The second order veins located in the lamina have the same characteristics as the midvein. The smaller veins usually have no bundle-sheath.

With regard to these general characteristics, variations can be observed among the samples studied:

- Thickness of the lamina. The statistical results show significant differences (with a significance level of $\mathrm{p}<$ 0.05 ) among the samples: the thinnest leaf lamina belongs to $Q$. robur, and the thickest corresponds to $Q$. xpuentei and Q. xpenasii.

- Epidermis. The epidermal cells of the adaxial are notably larger than the abaxial (Figure 1(a)). The adaxial cells are cuboidal and raised (Figure 1(a), Figure 1(e)), except in Q. robur and Q. orocantabrica, where they are seen to be low or very low and squamous (Figure 1(d), Figure 1(f)). The abaxial epidermis is constituted of small, cuboidal raised cells in all cases, and can be seen to be slightly squamous in $Q$. robur.

- Stomata. The epicuticular waxes in the guard cells of the stomata show three different patterns of density: they are scarce in Q. petraea and Q. xpuentei (Figure 1(i)), abundant in Q. robur and Q. orocantabrica 
(Figure 1(j)), and with intermediate densities in Q. pyrenaica and Q. xpenasii.

- Palisade parenchyma. It is constituted by two rows of cells. The first row consists of prosenchymatose cells without conspicuous intercellular spaces, while the second row comprises smaller cells with intercellular spaces in $Q$. orocantabrica, $Q$. petraea and $Q$. xpuentei. In $Q$. pyrenaica and $Q$. xpenasii the second cell layer is more compact (Figure 1(e)). In Q. robur the presence of a single cell layer is observed (Figure 1(f)).

- Trichomes. Glandular trichomes are observed on the abaxial surface of all samples. They are also observed on the adaxial—albeit very scarce—of $Q$. pyrenaica and $Q$. xpenasii. These same samples are the only ones to present non-glandular trichomes on the adaxial in addition to the abaxial. The glandular trichomes are all similar to each other. They are multicellular, and their distal cell (the furthest away from the epidermis) has a glandular appearance (Figures 2(c)-(e)). Non-glandular trichomes can be differentiated by the number of branches they have and by their length. In $Q$. petraea and $Q$. xpuentei, trichomes can be observed with four short branches which tend to be attached to the surface (Figure 2(f)). However in Q. pyrenaica and $Q$. xpenasii, trichomes can be observed with four branches, although they frequently have more. These trichomes are often found in bundles, with long branches remote from the surface of the epidermis (Figures 2(g)-(h)).

- Starch. The greatest presence is detected in Q. orocantabrica and Q. petraea (Figure 1(d)). The lowest presence is observed in $Q$. xpuentei.

- Crystals. Druses are observed in the spongy parenchyma in most of the samples studied. They are less frequent in Q. robur and Q. pyrenaica. In the midvein they have a greater presence in Q. xpenasii (Figure 1(i)).

\section{Discussion}

The fact that the species in the genus Quercus have dorsiventral and hypostomatic leaves with anomocytic stomata which are slightly raised above the surface of the epidermis is well-known and has been extensively documented. In addition to these characteristics, it should be noted that the six leaves studied in this present work have epicuticular waxes of the membranous platelet type on both the adaxial and the abaxial surface. In spite of these common characteristics of Quercus leaves, there is a great morphological variability in the genus [4] which hinders its taxonomy, and even more so when considering the ease with which interspecies hybridisations occur [4] [5]. This is the case of two of the species analysed here: Q. xpuentei, a hybrid of Q. orocantabrica and $Q$. petraea; and $Q$. xpenasii, a hybrid of $Q$. orocantabrica and $Q$. pyrenaica.

As has been indicated, when proposing a comparative morphological study between species, special care must be taken when collecting the samples. This has been taken into account in the present work, and samples have always been taken from the periphery of the tree (and not from the interior), and never from plants on the outer edges of the tree stands. It should be noted that ecological factors (in the broad sense) may affect the leaf morphology, including the morphology of the epicuticular waxes [32] [35] [36]

All the species studied were positive in the reaction with Lugol; that is, in all cases the presence of starch was detected. Given that the amount of starch was estimated subjectively by the observer, the results need to be confirmed by future biochemical analyses. The result of these analyses will make it possible to quantify the amount of starch in the leaves, and this can perhaps be related to the rate of photosynthesis in each plant [16]. The advisability of performing analyses to establish the amount of starch in the leaves in the study also applies to the presence of crystals, for the same reasons.

In agreement with numerous authors, the Quercus leaves we have studied show two types of trichomes: some non-glandular, which have classically been used as tools in taxonomy; and others glandular, which have not been used [22] [23]. These glandular trichomes have been observed in the six species studied. These are multicellular trichomes with a single-cell head which is strictly glandular, while the remaining supporting cells are non-glandular [37]. Images of these trichomes can often be seen in the bibliography on the taxonomy of Quercus and other genera with a non-existent or totally retracted head. These images should be considered as artefacts resulting from the technique used for the observation of the samples in SEM.

When establishing similarities between the species studied, it is possible to refer to two groups, excluding hybrids: on the one hand Q. robur and Q. orocantabrica; and on the other hand, Q. petraea and Q. pyrenaica. The two species in the first group share the fact that they have squamous cells on the adaxial epidermis, a high density of epicuticular waxes on the stomata, and the presence of only glandular trichomes and only on the abaxial surface of the leaf. It is true that $Q$. robur has a significantly thinner lamina compared to $Q$. orocantabrica (of all 
the species studied) and that it has predominantly a single cell layer on the palisade parenchyma.

The other group proposed (Q. petraea and Q. pyrenaica) differs from the previous group in having nonglandular trichomes in addition to glandular trichomes. However, in the case of Q. petraea they are located only on the abaxial surface and have four branches; whereas Q. pyrenaica has both types of trichomes, both on the adaxial and the abaxial surface, and the non-glandular trichomes are observed to have four or more branches.

With regard to the study of the hybrids, it is noted that both share a thickness of lamina which is significantly higher than the rest of the species studied. Furthermore, Q. xpuentei is seen to have common characteristics with Q. petraea, and Q. xpenasii with Q. pyrenaica.

Q. xpuentei and $Q$. petraea share: 1) a low density of epicuticular waxes in the stomata; 2) a palisade parenchyma with one compact cell layer and a second less compact layer (a characteristic it shares with $Q$. orocantabrica); and 3) the presence in both cases of trichomes with four branches on the abaxial leaf surface. Q. xpenasii and Q. pyrenaica share: 1) a similar density in epicuticular waxes associated to the stomata; 2) the presence of a palisade parenchyma constituted by two layers of compact cells; 3) the presence of glandular and non-glandular trichomes both on the adaxial and abaxial surfaces; and 4) the presence of non-glandular trichomes with four or more branches, generally in bundles and protruding from the epidermis.

It is particularly worth noting the fact that in addition to the so-called "classic" characteristics of the different species with regard to trichomes, stomata and epicuticular waxes generally studied with SEM, the present study highlights other further characteristics. These characteristics derive mainly from the study of the histological sections: thickness of the lamina, shape of the epidermal cells, characteristics of the chlorophyll parenchyma, presence of crystals, etc. which should be used in future works. These structural characteristics are of undoubted value to the taxonomy of the species in the Quercus genus and their frequent hybrids.

In view of the set of characteristics studied, an identification key is proposed for the differentiation of the six taxa studied in this present work:

1. Leaves with only glandular trichomes... 2

1. Leaves with glandular and non-glandular trichomes... 3

2. Thin leaf $(0.124 \mu \mathrm{m}(\leq 0.180 \mu \mathrm{m}))$, chlorophyll parenchyma with one cell layer, squamous cells on the abaxial epidermis, few crystals... Q. robur

2. Thick lamina $(0.218 \mu \mathrm{m}(>0.180 \mu \mathrm{m}))$, chlorophyll parenchyma with $1+1$ cell layers, cuboidal cells in the abaxial epidermis, abundant crystals... Q. orocantabrica

3. Chlorophyll parenchyma with $1+1$ cell layers, guard cells with few epicuticular waxes, trichomes only on the abaxial surface, non-glandular trichomes with four short branches... 4

3. Chlorophyll parenchyma with two cell layers, guard cells with abundant epicuticular waxes, trichomes on both the adaxial and abaxial surfaces, non-glandular trichomes with four or more long branches, generally in bundles... 5

4. Thin lamina $(0.165 \mu \mathrm{m}(\leq 0.180 \mu \mathrm{m})) \ldots$ Q. petraea

4. Thick lamina $(0.218 \mu \mathrm{m}(>0.180 \mu \mathrm{m})) \ldots$ Q. xpuentei

5. Thin lamina $(0.177 \mu \mathrm{m}(\leq 0.180 \mu \mathrm{m})) \ldots$ Q. pyrenaica

5. Thick lamina $(0.218 \mu \mathrm{m}(>0.180 \mu \mathrm{m})) \ldots$ Q. xpenasii

\section{Descriptions}

The proposed new taxa are described, and histological additions are made to the existing taxa:

Quercus xpuentei S. Rivas Mart., T.E. Díaz, Penas, del Río, L. Herrero \& R. Álvarez nothosp. nova (=Q. orocantabrica Rivas Mart., Penas, T.E. Díaz \& Llamas $\times$ Q. petraea (Matt.) Liebl.).

Tree up to $35 \mathrm{~m}$. With marcescent leaves with glandular and non-glandular trichomes only on the abaxial surface. The non-glandular trichomes have four short branches.

Thick leaf lamina, measuring $0.218 \mu \mathrm{m}(>0.180 \mu \mathrm{m})$. Chlorophyll parenchyma with $1+1$ cell layers. Guard cells with few epicuticular waxes. Fruit peduncle measuring (14)-25-(38) mm.

Holotypus: León: Puerto de las Señales (9-8-2010) (30TUN1529970515) in an east-south-east orientation at 1386 m in beech forest. LEB 107.294. Leg. A. Penas, S. del Río, L. González de Paz \& I. Fuertes. Dedicated to Emilio Puente García.

Quercus xpenasii S. Rivas Mart., T.E. Díaz, del Río, L. Herrero \& R. Álvarez nothosp. nova. (=Q. orocantabrica Rivas Mart., Penas, T.E. Díaz \& Llamas $\times$ Q. pyrenaica Willd.). 
Tree up to $25 \mathrm{~m}$. Greyish-brownish bark. With marcescent pinnatifid or pinnatipartite leaves with glandular and non-glandular trichomes on both the adaxial and abaxial leaf surface. Non-glandular trichomes with four or more long branches, generally in bundles. Thick leaf lamina, measuring $0.218 \mu \mathrm{m}(>0.180 \mu \mathrm{m})$. Chlorophyll parenchyma with two cell layers. Guard cells with abundant epicuticular waxes. Fruit peduncle (16)-22-(34) $\mathrm{mm}$.

Holotypus. Valle del arroyo de Faeda (Cabrera Baja) (16-8-2010) (30TPG9320079207) at $1410 \mathrm{~m}$ in a western orientation. LEB 107296. Leg.: L. González de Paz, S. del Río \& A. Penas. Dedicated to our friend Ángel Penas Merino.

Quercus robur L. subsp. robur, Sp. Pl.: 996 (1753).

Tree with exclusively glandular trichomes and only on the abaxial leaf surface. Thin leaf lamina measuring $0.124 \mu \mathrm{m}(\leq 0.180 \mu \mathrm{m})$. Chlorophyll parenchyma with 1 cell layer. Cells on abaxial epidermis squamous. Few crystals.

Quercus orocantabrica Rivas Mart., Penas, T.E. Díaz \& Llamas, Itinera Geobot. 15(2): 706.

Tree with exclusively glandular trichomes and only on the abaxial leaf surface. Thick leaf lamina, measuring $0.182 \mu \mathrm{m}(>0.180 \mu \mathrm{m})$. Chlorophyll parenchyma with $1+1$ cell layers. Cuboidal cells on abaxial epidermis. Abundant crystals.

Quercus petraea (Matt.) Liebl., Fl. Fuld.: 4UN (1784).

Tree with non-glandular trichomes with four short branches, located only on the abaxial leaf surface. Thin leaf lamina, with a thickness of $0.165 \mu \mathrm{m}(\leq 0.180 \mu \mathrm{m})$. Chlorophyll parenchyma with $1+1$ cell layers. Guard cells with few epicuticular waxes.

Quercus pyrenaica Willd., Sp. Pl. 4: 451 (1805).

Tree with both glandular and non-glandular trichomes on both the adaxial and abaxial leaf surfaces. Nonglandular trichomes with four or more branches, long and generally in bundles. Thin leaf lamina, with a thickness of $0.177 \mu \mathrm{m}(\leq 0.180 \mu \mathrm{m})$. Chlorophyll parenchyma with two cell layers. Guard cells with abundant epicuticular wax.

\section{Acknowledgements}

We would like to thank Dr. Linda González de Paz and Inés Fuertes Gutiérrez for help in collecting the materials.

\section{References}

[1] Burger, W.C. (1975) The Species Concept in Quercus. Taxon, 24, 45-50. http://dx.doi.org/10.2307/1218998

[2] Stebbins, G.L. and Pérez de la Vega, M. (1989) Evolución: hacia una nueva síntesis. Contribución desde el reino vegetal. Servicio de publicaciones de la Universidad de León, 128 p.

[3] Rushton, B.S. (1993) Natural Hybridization within the Genus Quercus L. Annals of Forest Science, 50, 73s-90s. http://dx.doi.org/10.1051/forest:19930707

[4] Bussotti, F. and Grossoni, P. (1997) European and Mediterranean oaks (Quercus L.; Fagaceae): SEM Characterization of the Micromorphology of the Abaxial Leaf Surface. Botanical Journal of the Linnaean Society, 124, 183-199.

[5] Scareli-Santos, C., Herrera-Arroyo, M.L., Sanchez-Mondragon, M.L., Gonzalez-Rodriguez, A., Bacon, J. and Oyama, K. (2007) Comparative Analysis of Micromorphological Characters in Two Distantly Related Mexican Oaks, Quercus conzattii and Q. eduardii (Fagaceae) and Their Hybrids. Brittonia, 59, 37-48. http://dx.doi.org/10.1663/0007-196X(2007)59[37:CAOMCI]2.0.CO;2

[6] Dupouey, J.L. (1983) Analyse multivariable de quelques caractères morphologiques de populations de chênes (Quercus robur L. et Quercus petraea (Matt.) Liebl.) du Hurepoix. Annales de Sciencies Forestières, 40, 265-282. http://dx.doi.org/10.1051/forest:19830303

[7] Dupouey, J.L. and Le Bouler, H. (1989) Discrimination morphologique des glands de chênes sessile (Quercus petraea (Matt.) Liebl.) et pédonculé (Quercus robur L.). Annales de Sciencies Forestières, 46, 187-194. http://dx.doi.org/10.1051/forest:19890207

[8] Yacine, A. and Lumaret, R. (1989) Genetic Diversity in Holm-Oak (Quercus ilex L.): Insight from Several Enzyme Markers. Silvae Genetica, 38, 3-4.

[9] Kremer, A. and Petit, R.J. (1993) Gene Diversity in Natural Populations of Oak Species. Annales de Sciencies Forestières, 50, 186s-202s. http://dx.doi.org/10.1051/forest:19930717 
[10] Rafii, Z.A., Dodd, R.S. and Pellau, Y. (1993) Mediterraneal Overgreen Oak Diversity: Morphological and Chemical Variations of Acors. Canadian Journal of Botany, 70, 1459-1466. http://dx.doi.org/10.1139/b92-184

[11] Dupouey, J.L. and Badeau, V. (1993) Morphological Variability of Oaks (Quercus robur L., Quercus petraea (Matt) Liebl, Quercus pubescens Willd.) in Northeastern France: Preliminary Results. Annals of Forest Science, 50, 35s-40s. http://dx.doi.org/10.1051/forest:19930702

[12] Bruschi, P., Vendramin, G.G., Bussotti, F. and Grossoni, P. (2000) Morphological and Molecular Diffrentiation between Quercus petraea (Matt.) Liebl. and Quercus pubescens Willd. (Fagaceae) in Northern and Central Italy. Annals of Botany, 85, 325-333. http://dx.doi.org/10.1006/anbo.1999.1046

[13] Bussoti, F., Borghini, F., Celesti, C., Leonzio, C. and Bruschi, P. (2000) Leaf Morphology and Macronutrients in Broadleaved Trees in Central Italy. Trees, 14, 361-368. http://dx.doi.org/10.1007/s004680000056

[14] Nikolić, N., Merkulov, L.J., Pajević, S. and Krstić, B. (2005) Variability of Leaf Anatomical Characteristics in Pedunculate Oak Genotypes (Quercus robur L.). Proceedings of the Balkan Scientific Conference of Biology, Plovdiv, 19-21 May 2005, 240-247.

[15] Penas, A., Llamas, F., Pérez-Morales, C. and Acedo, C. (1994) Aportaciones al conocimiento del género Quercus en la Cordillera Cantábrica. I. Tricomas foliares de las especies caducifolias. Lagascalia, 17, 311-324.

[16] Taiz, L. and Zeiger, E. (2010) Plant Physiology. 5th Edition, Sinauer Associates Inc., Sunderland, 782 p.

[17] Schicchi, R., Mazzola, P. and Raimondo, F.M. (2001) Eco-Morphologic and Taxonomic Studies of Quercus Hybrids (Fagaceae) in Sicily. Bocconea, 13, 485-490.

[18] Llamas, F., Perez-Morales, C., Acedo, C. and Penas, A. (1995) Foliar Trichomes of the Evergreen and Semideciduous Species of the Genus Quercus (Fagaceae) in the Iberian Peninsula. Botanical Journal of the Linnean Society, 117, 47-57.

[19] Ishida, T.A., Hattori, K., Sato, H. and Kimura, M.T. (2003) Differentiation and Hybridization between Quercus crispula and Q. dentata (Fagaceae): Insights from Morphological Traits, Amplified Fragment Length Polymorphism Markers, and Leafminer Composition. American Journal of Botany, 90, 769-776. http://dx.doi.org/10.3732/ajb.90.5.769

[20] Panahi, P., Jamzad, Z., Pourmajidian, M.R., Fallah, A. and Pourhashemi, M. (2012) Foliar Epidermis Morphology in Quercus (subgenus Quercus, section Quercus) in Iran. Acta Botanica Croatica, 71, 95-113. http://dx.doi.org/10.2478/v10184-010-0029-y

[21] Nikolić, N.P., Merkulov, L.S., Krstić, B.D. and Orlović, S.S. (2003) A Comparative Analysis of Stomata and Leaf Trichome Characteristics in Quercus robur l. Genotypes. Proceedings for Natural Sciences, 105, 51-59.

[22] Thomson, P.M. and Mohlenbrock, R.H. (1979) Foliar Trichomes of Quercus in the Eastem United States. Journal of the Arnold Arboretum, 60, 350-366.

[23] Valencia, S. and Delgado, A. (2003) Los tricomas foliares en la caracterización de un grupo de especies del género Quercus, sección (Fagaceae). Anales del Instituto de Biología, Universidad Nacional Autónoma de México, Serie Botánica, 74, 5-15.

[24] Dyal, S.C. (1936) Akey to the Species of Oaks of Eastern North America Based on Foliage and Twig Characters. Rhodora, 38, 53-63.

[25] Hardin, J.W. (1976) Terminology and Classification of Quercus Trichomes. Journal of Elisha Mitchell Science Society, 92, 151-161.

[26] Hardin, J.W. (1979) Patterns of Variation in Foliar Trichomes Eastern North American Quercus. American Journal of Botany, 66, 576-585. http://dx.doi.org/10.2307/2442507

[27] Hardin, J.W. (1979) Atlas of Foliar Surface Feactures in Woody Plants. l. Vestiture and Trichome Types of Eastern North American Quercus. Bulletin of the Torrey Botanical Club, 106, 315-325. http://dx.doi.org/10.2307/2560358

[28] Jones, J.H. (1986) Evolution of the Fagaceae: The Implications of Foliar Features. Annals of Missouri Botanical Garden, 73, 228-275. http://dx.doi.org/10.2307/2399112

[29] Barthlott, W., Neinhuis, C., Cutler, D., Ditsch, F., Meusel, I., Theisen, I. and Wilhelmi, H. (1998) Classification and Terminology of Plant Epicuticular Waxes. Botanical Journal of the Linnean Society, 126, 237-260. http://dx.doi.org/10.1111/j.1095-8339.1998.tb02529.x

[30] Tulloch, A.P. (1976) Chemistry of Waxes of Higher Plants. In: Kolattukudy, P.E., Ed., Chemistry and Biochemistry of Natural Waxes, Elsevier, Amsterdam, 235-287.

[31] Uzunova, K. (1999) A Comparative Study of Leaf Epidermis in European Corylaceae. Feddes Repertorium, 110, 209218. http://dx.doi.org/10.1002/fedr.19991100307

[32] Tomaszewski, D. (2004) The Wax Layer and Its Morphological Variability in Four European Salix Species. Flora, 199, 
320-326. http://dx.doi.org/10.1078/0367-2530-00159

[33] Uzunova, K. and Palamarev, E. (1993) An Investigation of the Leaf Epidermis of the European (Non-Balkan) Species of the Genus Quercus. Fitologia, 45, 3-15.

[34] Luo, Y. and Zhou, Z.K. (2001) Cuticle of Quercus Sugen. Cyclobalanopsis (Oerst.) chneid. (Fagaceae). Acta Phytophysiologica Sinica, 39, 489-501.

[35] Safou, O., Saint Martin, M. and Rouane, P. (1988) Stomates et cires dans le genre Quercus. Comptes Rendus de l'Académie des Sciences, Série III, Sciences de la Vie, 307, 701-707.

[36] Gülz, P.G. (1994) Epicuticular Leaf Waxes in the Evolution of the Plant Kingdom. Journal of Plant Physiology, 143, 453-464. http://dx.doi.org/10.1016/S0176-1617(11)81807-9

[37] Evert, R.F. (2006) Esau’s Plant Anatomy: Meristems, Cells, and Tissues of the Plant Body: Their Structure, Function, and Development. 3rd Edition, Jonh Wiley and Son, New Jersey, 601 p. http://dx.doi.org/10.1002/0470047380 
Scientific Research Publishing (SCIRP) is one of the largest Open Access journal publishers. It is currently publishing more than 200 open access, online, peer-reviewed journals covering a wide range of academic disciplines. SCIRP serves the worldwide academic communities and contributes to the progress and application of science with its publication.

Other selected journals from SCIRP are listed as below. Submit your manuscript to us via either submit@scirp.org or Online Submission Portal.
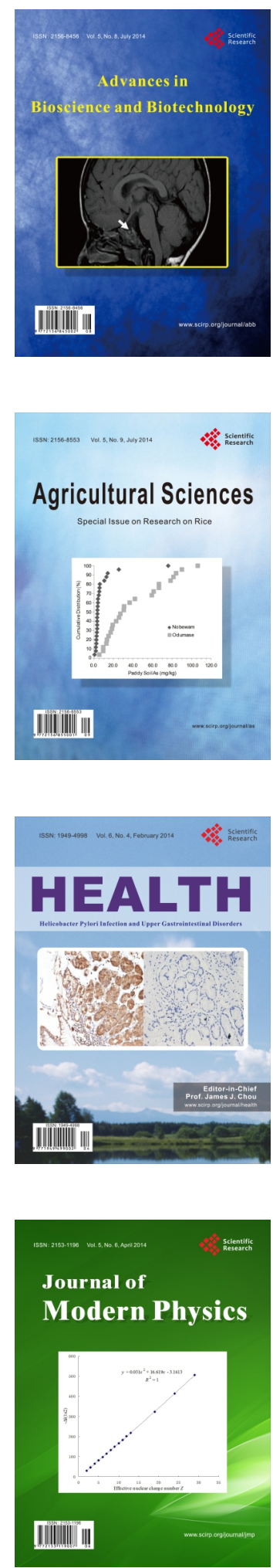
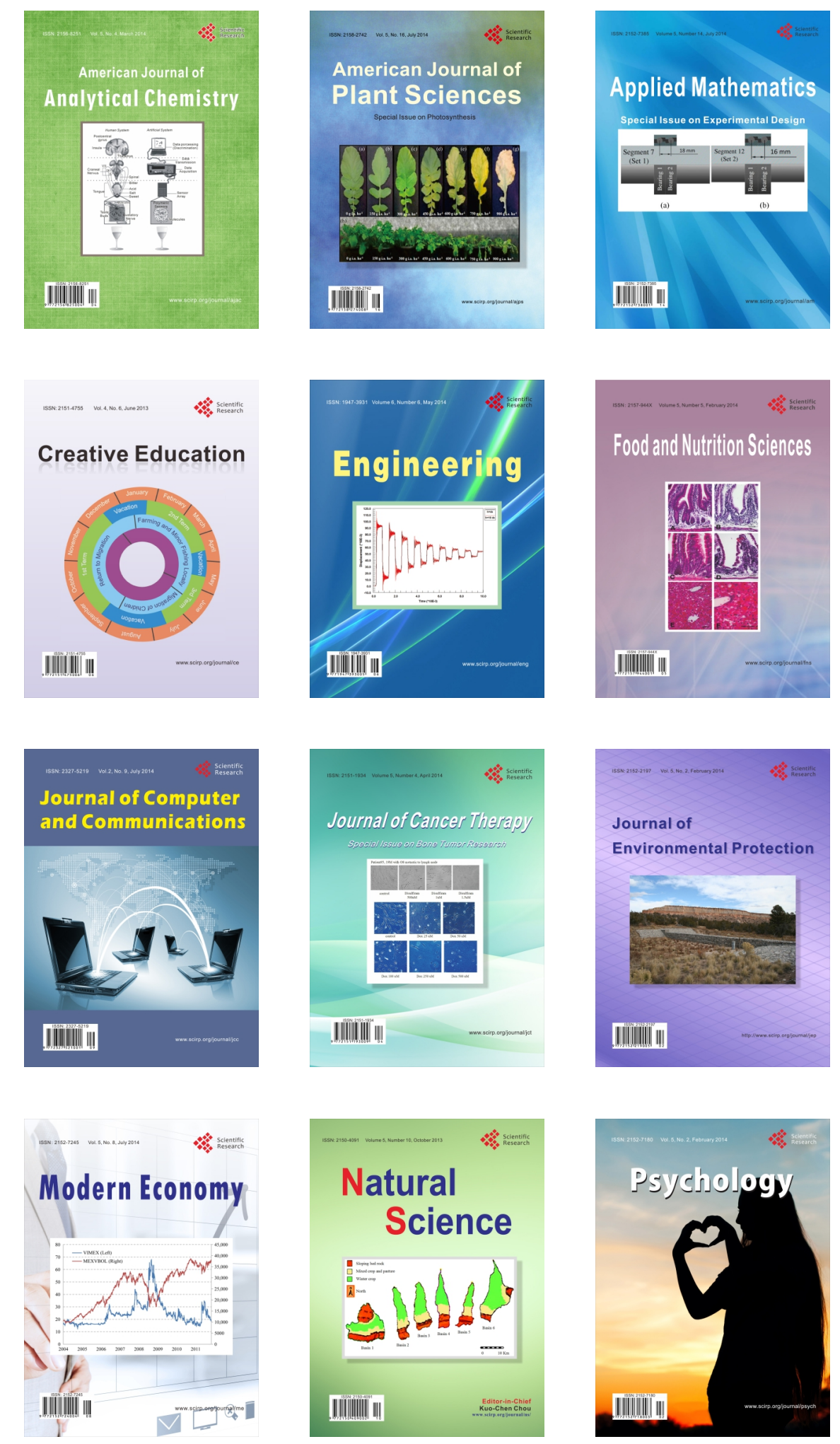